狭さく部を有する水路の流れについて

Flow through Constriction in an Open Channel

\begin{tabular}{|c|c|}
\hline 早稲田大学大学院 & 学生員 \\
\hline 早䄶田大学理工学部 & 正 員 \\
\hline 東洋大学工学部 & 正 員 \\
\hline 早秪田大学理工学部 & 学生員 \\
\hline
\end{tabular}

1. はじめに

局所流による河床変動は、河川全体での巨視的な流砂の収支関係に影響を及ぼすととあに、より直接的に は河川構造物や河岸の維持管理に対しても大きな影響を与えている。したがって、ての問題の解明は重要な 課題の一つといえる。本研究においては特に狭さく部を通過する流れを解析の対象とし、局所的な河床変動 解明の第一段階として滑面固定床での底面せん断力の算定を試みた。一般に底面せん断力は、流れを等流近 似し力のつりあい関係から求める方法などが考えられるが、流線が急激に曲かるいわゆる急変流に対しては ての方法では十分な見積りができないことは周知である。また古典的な手法として流れを底面の影響を受け る境界層の領域と、いわゆるポテンシャル流れとして見なせる領域にわけ、境界層方程式を解くことにより 底面せん断力を算出する方法がある。片山ら ${ }^{1)}$ はこの解析法に改良を加え、段落ち流れにおける近似的な底 面せん断力の算定法を工夫しているが、我々はての手法をさらに拡張し、3 次元的な流れである今回の狭さ く部を通過する流れに適用することを考えた。また実験的に狭さく部下流側における底面せん断力の分布を 求め、その分布特性および最大底面せん断力の簡易推定法をああわせて論じる。

\section{2. 実験装置・実験方法}

幅 $54.5 \mathrm{~cm}$ 、長さ約 $5 \mathrm{~m}$ 、勾配 $1 / 75$ の广クリ ル製の水路の長手方向のほぼ中央に、開口幅 $18 \mathrm{~cm}$ の狭さく部を設け、乙れを実験に使用 する（図 1 ）。実験ケースとして、流量 $\mathrm{Q}=$ $23.0 \ell / \mathrm{s}$ に対して、水路下流端を開放し、狭 さく部通過後射流状態となるもの（ C a s e 1、 (わゆる射流遷移）と下流端に高さ $18.35 \mathrm{~cm}$ のせきを設け流れ全域にわたって常流となるあ の ( C a s e 2、いわゆる常流遷移) の 2 ケース を行い、数值解析の対象とした。この 2 ケース の水面形を図 2 に示す。

また、射流遷移の場合を対象として、上流で の水深を変化させ、流量の変化と狭さく部下流 部において底面でのせん断力が最大となる場所 とその大きさの変化を調べた。

底面せん断力の実測は、プレストン 2) の手法 にならい、外径と内径の比が 0.6 のピト一管を 用いた。なお、等流状態でプレストン管の較正 を行い、今回の実験条件はその適用が可能な範 囲であることを確認した。

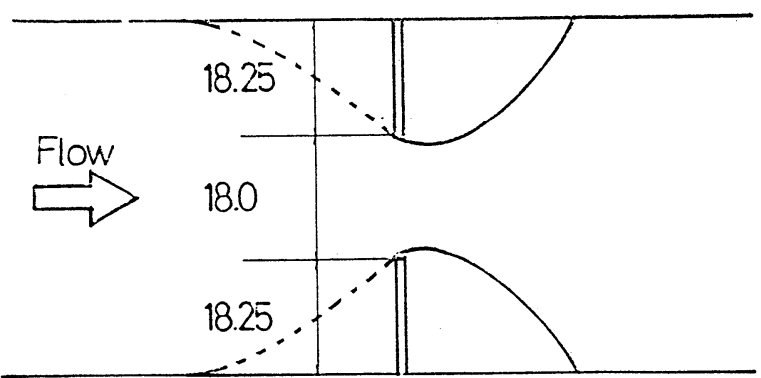

図 1. 実験水路

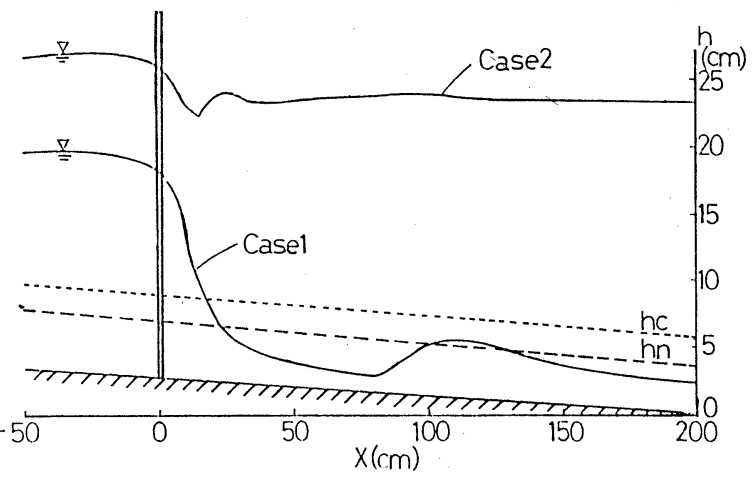

図 2. Case1. Case 2. 中央測線に沿う水面形 


\section{3. 底面せん断力の算定の基本的考え方}

本研究の底面せん断力の算定法に対する基本的立場は参考文献1)に詳述してあるが、本研究の目的を明確 にするためててで簡単に述べておく。

文献1)においては段落ち流れという 2 次元急変流の解析を行なっているが、今回その解析法を 3 次元流れ である本研究に対してあ適用できることを確認できたのでててでの説明は 2 次元として行う。

今、我々は図 3 亿示すような流速分布を持つ 3 つの流 れの場を想定する。(1)流れが実際の狭さく部を通過す る流れであり、(2)流れは排除厚が非常に薄いと考えて 流れ全域にわたってポテンシャル流れとする流れの場で ある。流線の曲がりなどにより鉊直力を受けている実際 の流れ(1に対して境界層方程式を解くことは、究極のと ころナビエ・ストークスの方程式をそのまま解くことに 相当し実際上その解析は困難なあのとなる。そこで我々 は、境界層方程式を(1)流れに対して適用するのではな く、鉊直力の影響を受けていないとする(3)の流れに対し て境界層方程式を展開して行くことを考える。すなわち

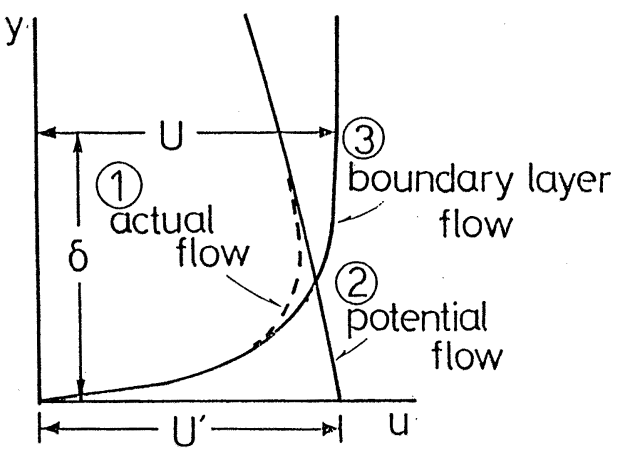

図 3. 流れの場概念図 (3)の流れは底面の極近傍では実際の流れ(1)よく表現しているが、その上部では鉛直力の働かない無限の水 深を持つ理想的な流れであると考える。こてで流れ方向に $\mathrm{x}$ 軸、鉊直上向きに $\mathrm{y}$ 軸をとれば、(3の流れの境 界層に対するナビエ・ストークスの方程式は、 $\mathrm{x}$ 方向に対して、若干のオーダー比較による項の整理の後、

$$
\mathrm{u} \frac{\partial \mathrm{u}}{\partial \mathrm{x}}+\mathrm{v} \frac{\partial \mathrm{u}}{\partial \mathrm{y}}=-\frac{1}{\rho} \frac{\partial \mathrm{p}}{\partial \mathrm{x}}+\nu \frac{\partial \mathrm{u}}{\partial \mathrm{y}^{2}}
$$

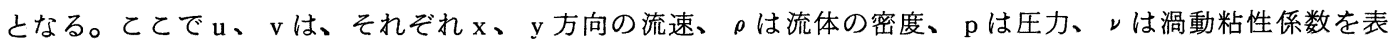
わすあのとする。さらに $\mathrm{y}$ 方向に対しては

$$
-\mathrm{g}-\frac{1}{\rho} \frac{\partial \mathrm{p}}{\partial \mathrm{y}}=0
$$

を得る。(3)の流れの境界層内では圧力分布は、 $\mathrm{y}$ 方向力がないてとを考えると傾きが $45{ }^{\circ}$ の分布になってい ると考えられる。したがってててで、位置水頭を圧力 $\mathrm{p}$ としに一つのポテンシャルと考え、両者をあわせ てポテンシャル $\mathrm{p}^{\prime}$ とするならば、2)式は

$$
\frac{\partial \mathrm{p}^{\prime}}{\partial \mathrm{y}}=0
$$

のように書ける。すなわち重力場においてあ、压力の静水圧分布を仮定できるならばプラントルの境界層方 程式之同様の結果が得られることがわかる。(3)の流れの境界層外縁で一様ポテンシャル流速Uを持ち、 $\mathrm{y}=\delta$ で $\partial \mathrm{u} / \partial \mathrm{y}=0$ という境界条件を 1 ) 式に用いれば、

$$
\mathrm{U} \frac{\partial \mathrm{U}}{\partial \mathrm{x}}=-\frac{1}{\rho} \frac{\partial \mathrm{p}}{\partial \mathrm{x}}
$$

を得、我々の仮想している(3)の流れに対しては、压力の $\mathrm{x}$ 方向変化を主流速 $\mathrm{U}$ の変化で代用し得るてとにな る。連続の式を使用し、カルマンにならって1)式から運動量方程式を導けば、

$$
\frac{\partial}{\partial \mathrm{x}}\left(\mathrm{U}^{2} \theta\right)+\delta^{*} \mathrm{U} \frac{\partial \mathrm{U}}{\partial \mathrm{x}}=\frac{\tau_{0}}{\rho}
$$

になる。ことに $\theta$ は運動量厚、 $\delta^{*}$ は排除厚、 $\tau_{0}$ は底面せん断力である。境界層内の流速分布に次式のべき乗 則を適用するととにし、

$$
\mathrm{u}(\mathrm{y})=\mathrm{U}(\mathrm{y} / \delta)^{\frac{1}{\mathrm{n}}} \delta: \text { 境界層厚 }
$$


流速分布の実測により $\mathrm{n}=7$ とし、流れ方向にわたって $\mathrm{n}$ の值が変化しないとすれは、6）式は、

$$
\frac{7}{72} \mathrm{U}^{2} \frac{\partial \delta}{\partial \mathrm{x}}+\frac{23}{72} \delta \frac{\partial \mathrm{U}}{\partial \mathrm{x}}=\frac{\tau_{0}}{\rho}
$$

と変形できる。ここでブラジゥスの抵抗則

$$
\frac{\tau_{0}}{\rho}=0.0225 \mathrm{U}\left(\frac{\mathrm{U} \delta}{\nu}\right)-\frac{1}{4}
$$

と7)式を連立させれば、主流速Uを与えることにより底面せん断力 $\tau_{0}$ が算出できるととになる。したがって (3)流れの底面せん断力を上記の方法で求めれば、(3)の流れの底面近傍は(1)の実際の流れの底面近傍の様子 を忠実に表現しているので、こてで求まる底面せん断力を実際の流れの底面せん断力と見なすてとができよ う。しかしながら、この時(3)流れの主流速Uを見積ることは実際上困難と思われるので、本解析において はポテンシャル流(2)の底面流速Uを用いるととにする。なぜなら、(3)の流れが(1)の流れに重力以外の外力の 働かない場合に相当するてとを考えると、ポテンシャル解析での流速を使用する以上流線の曲がりのない場 ( 鉊直力の一番働いていない部分) である底面の流速をての解析に用いることが最あ妥当であると考えるか らである。

\section{4. ポテンシャル解析}

3.で述べてきたように、カルマンの運動量方程式を用いて底面せん断力 $\tau_{0}$ を算出するには、ポテンシャル 解析により底面でのポテンシャル流速Uを求める必要がある。狭さく部を通過する流れは 3 次元的に流線が 曲がっているので、3 次元のポテンシャル解析を行わ枋ばならいが、その解析は非常に手間がかかるため ててでは、2 次元のポテンシャル解析を組み合わせるととから 3 次元流れへアプローチしてゆく。すなわち 図 4 に示すように流れを横から見た平面と上から見た平面で構成 されているあのと考え、それぞれの平面に対して 2 次元のポテン シャル解析を行いそれぞれの平面での流線図よりある線に沿って 流管を組み立てるととにする。ての流管を通る流量は一定である から、各点での断面積がわかればその点の流速がわかるてとにな る。さて、上に述べたポテンシャル解析を行うには、解析する平 面の境界形状を決めてやらねばならない。そてでまず狭さく部を

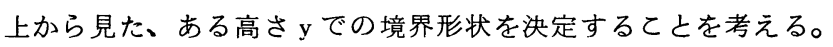
周知のでとく狭さく部に向かう流れは、狭さく部のかなり上流側 ではく離する。ポテンシャル解析はてのはく離している部分を除 いた形状に対して行わねばならないが、はくり点の位置は水路境 界面の粗度、王力の变化、流れのフルード数およびレイノルズ数 等によって大きく変化すると考えられ、狭さく部近傍においての これらの関係を解析的に導くことは困難と思われる。また、こて では、はく離点の位置を解析的に決定することは我々の目的に直 接には関与しないと考え、実験的にその位置を測定する。図 5 に

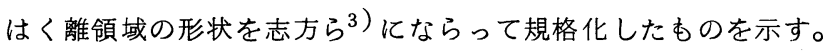
志方らは、狭さく幅とはく離点の狭さくからの距離で無次化した $\mathrm{x}^{\prime} \mathrm{n}_{+} \mathrm{z}^{\prime \mathrm{n}}=1$ とするはく離曲線を与え、条件により $\mathrm{n}=1 / 2 \sim$ $1 / 3$ 之変化させているが、我々は実測から $\mathrm{n}=0.7$ を取ることに

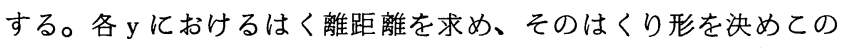
境界に対してポテンシャル解析を行う。ポテンシャル解析には数

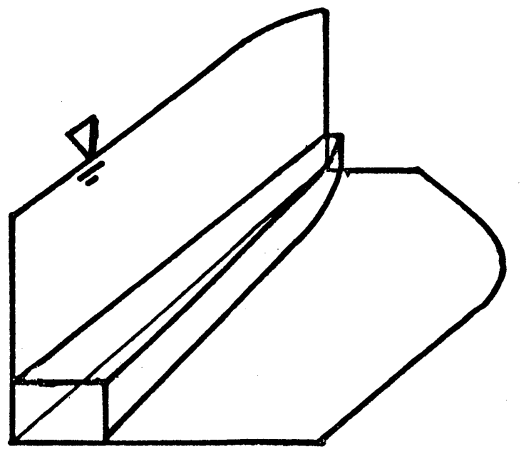

図 4. 流管の概念図

プロットの違いは 高さ $\mathrm{y}$ の違いを表わす

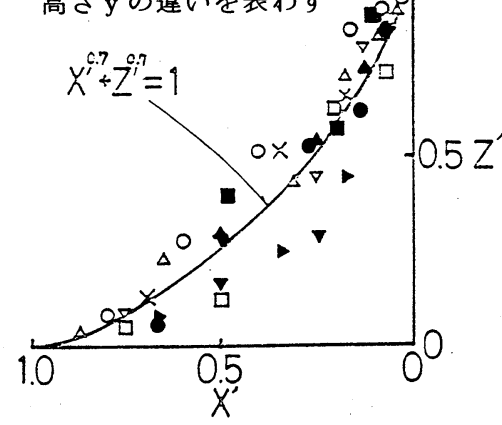

図 5. 無次元化したはくり形 
々の手法があるが、今回は特に境界要素法を用いた。以下に、本ケースに対するポテンシャル解析の適用を

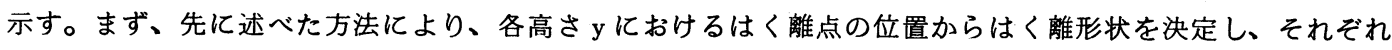
の境界形に対してポテンシャル解析 を行う。その結果を用いて、それぞ れの平面で適当な流れ関数值の間隔 で流線を描く。次に中央測線上の水 面形を境界とする横加見た平面に 対して同様にポテンシャル解析を行 い流線図を描く。てれら上から見た 流線図之横加見た流線図を図 4 の ような組み合わせにより、流管を形 成させ、それぞれの流線間隔より各 点の断面積を求める。乙の得られた 断面積を用い各流管での連続条件か ら各点での流管断面平均流速が算出

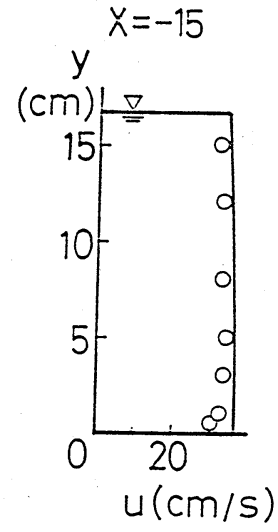

$$
x=-10
$$$$
x=-5(\mathrm{~cm})
$$
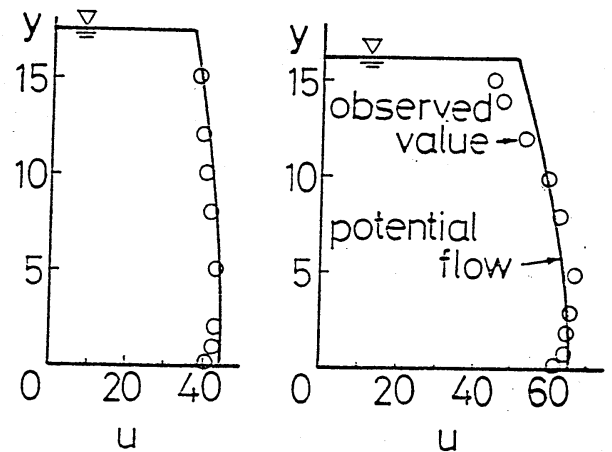

図 6. ポテンシャル解析による流速分布

できる。てのようにして求めた中央 測線上の流速分布を、実測值ととも に図 6 に示す。実線が流管から求め た流速で、各流管の高さの $1 / 2$ 点 に得られた流速をプロットして結ん だものである。

また、エネルギー高がポテンシャ ル解析の始点となる最上流面内で一 定、すなわち静水圧分布、一様流速 分布を仮定し、狭さく部上流側での エネルギー損失を無視して（実験的 にあほぼ確認できた）流管に沿って
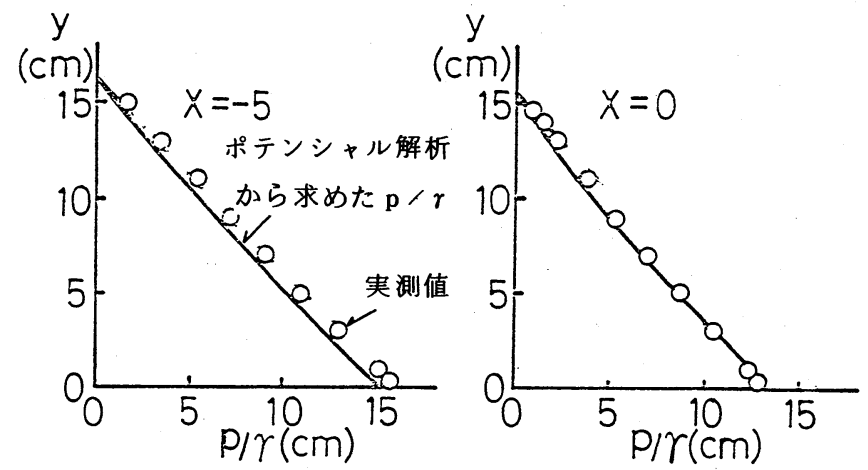

図 7. ポテンシャル解析による圧力分布

ベルヌーイの式を用いれば、各断面での圧力分布を知ることができる。てれは図 7 とて示してある。

図 6、図7で示されるように、今回行った、上から見た流線図と横から見た流線図の組み合わせによる流 管での解析はよく実測値と合致している。したがってての解析法を用いて 3.で述べた底面せん断力算定の際 のポテンシャル流速U'を得ることができる。

\section{5. 底面せん断力の算定}

急変流である狭さく部を通過する流れの底面 せん断力を見積るためには、流線の曲がりによ る遠心力等の外力の影響を考慮に入れた解析を 行うべきである。しかし先に述べた様に境界層 に対して影響を持つ項をすべて基本方程式に持 ち込み、これを厳密に解くことはかなり困難な 作業と思われる。急変流での底面せん断力をよ り簡便に求めることを目的亡するならば、底面 のごく近傍の流れの様子がわかればよいと考え

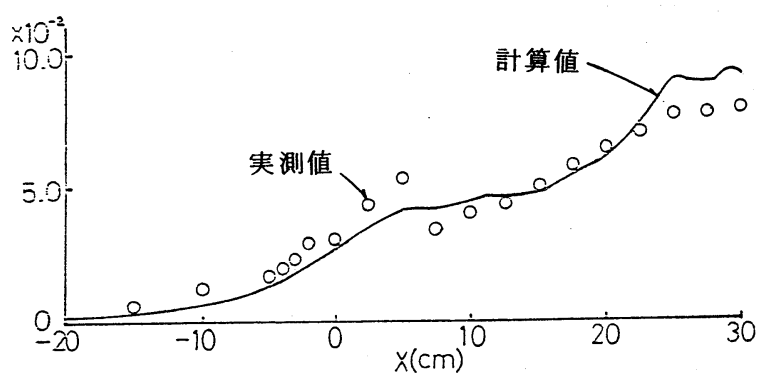

図 8. Case 1 中央測線上の底面せん断力 
本研究では 3. で述べた様な理想化した仮想流 れに対して境界層方程式を解くことにする。す なわち、底面のでく近傍では実際の流れを忠実 に表現するが、その上部ではカルマンの仮定を 满足しているとする流れを解析の対象として先 の(7)式、(8)式を連立させて解くてとになる。て の計算は(7)式、(8)式を差分化して、ポテンシャ ル解析の結果得られた主流速の変化を逐次代入 して底面せん断力 $\tau_{0}$ を求めるものであるが、計 算始点での境界層厚 $\delta$ を初期值として入力しな

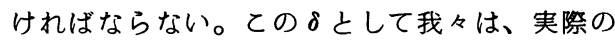
流れでの乱流境界層の十分発達した等流部の水 梁を与えた。乙の場合、乙の時の $\delta$ は我々の仮 想している流れでの水深を意味するすのではな く、あくまで仮想流れでの境界層厚を表現する あのとなる。てのようにして、Case1、および Ca se2の中央測線に浻って底面せん断力を算出 したあのを図 8、図9として示す。ててで夷線 が計算結果であり、プロットがプレストン管に よる実測值を表わしている。計算値は㬰測值を かなりよい精度で表現しているといえよう。こ の場合、ポテンシャル解析で我々の想定してい る流管は、中央測線上の底面に直線的に置かれ たものであるが、さらに別の流管 $(\mathrm{X}-\mathrm{Z}$ 平面 内で曲がった流管）に対して同様の解析を行っ てみた。すなわち流管に治って $\mathrm{S}$ 軸を設け、乙 の軸に対するポテンシャル流速U'の変化をカル

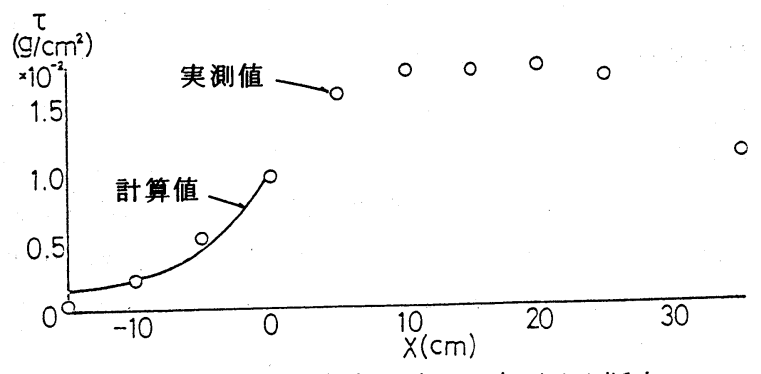

図 9. Case 2 中央測線上の底面せん断力

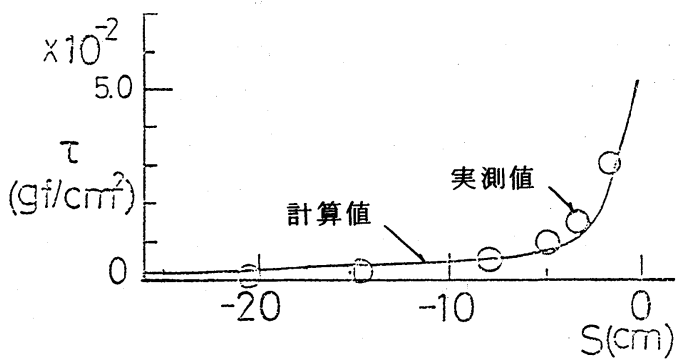

図 10. Case 1 S 軸に沿う底面せん断力

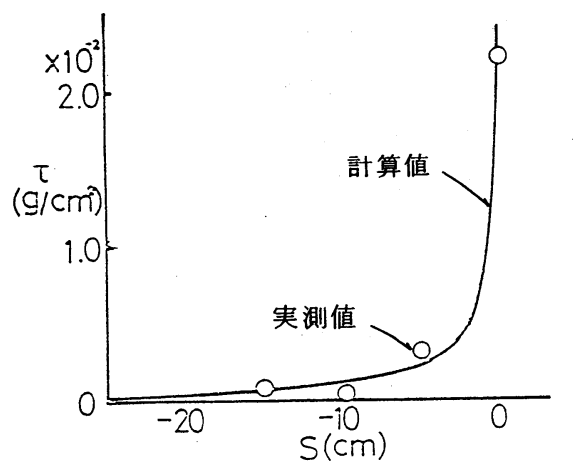

図 11. Case 2 S 軸に沿う底面せん断力 マンの運動量方程式に代入し底面女ん断力 $\tau_{0}$ を求める。ての結果は図 10 、図 11 に示す。解析は狭さく部上流 側で行い、 $\mathrm{S}=0$ が狭さく部に相当している。流管が曲がっている場合にも、底面せん断力は妥当に評価し 得るととが判る。

\section{6. 底面せん断力の分布および最大底面せん断力の簡易推定法}

5.においては、主として狭さく部上流側での流れ方向の底面せん断力の変化を見てきたが、こてでは、 狭さく部下流側での底面せん断力の横断方向の分布特性を考えてみる。解析の対象として Case1を用いた。 基本的にはてれまでの解析の様に、流管をポテンシャル解析から決定しなりればならないが、水面形が横断 方向に変化しているため、中央測線での水面形をそのまま横から見た境界形として解析に持ち込むてとはで きない。そてで、それぞれ計算を進める流管に対して、その流下距離と中央測線での流下距離とを対応さ廿 ることで、すでにわかっている中央測線での流管高さを近似的に使用して解析を行う。すなわち、中央測線 以外に置かれた流管む、流管の高さは中央測線上の流管之狭さく部加の距離に比例して同様に変化してい るものと考える。てのような流管に対して計算を行った結果を図 12 に示す。白丸が実測の底面せん断力で、 黒丸が計算によるものである。狭さくからの流下距離が $5 \mathrm{~cm}$ 程度では $(\mathrm{X}=5)$ 横断方向にわたる底面せん 断うの分布順向はよく表わしているものの、さらに流下すると、流れの外側での実測值とのずれが目立つ。 
したがって、流下につれてポテンシャル解析を適用できる領: 域が制限されてくるあのと思われる。

以上、ポテンシャル解析により底面せん断力を求めてきた が、ここでは射流遷移の場合での最大せん断力を簡便に知る ことを試みる。今、狭さく部より開口幅の 2 倍程度上流の点 と狭さく部の間でエネルギー式を考える。狭さく部で限界水
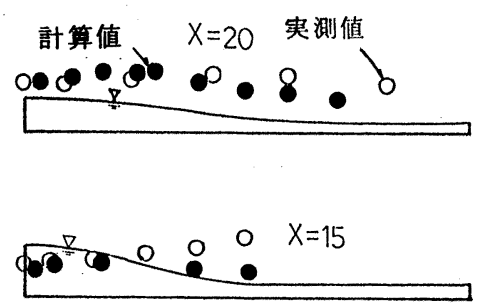
深が発生すると仮定すると、ベルヌーイの式

$$
\frac{Q^{2}}{2 g^{2} h^{2}}+h+Z=\frac{Q^{2}}{2 g^{2} h_{c}^{2}}+h_{c}
$$

加ら、上流水深 $\mathrm{h}$ は、流量 $\mathrm{Q}$ 、水路幅 $\mathrm{B}$ 、狭さく開口幅 $\mathrm{b}$ 、 の関係として与えることができる。との h V関する 3 次方程 式を $\mathrm{Q} 、 \mathrm{~B} 、 \mathrm{~b}$ を与えて解くと、求まる水梁之実測の水梁之 が一定比 (今回は 0.94 ) となることがわかった。つまり流 量 $\mathrm{Q}$ をええる゙けで、上流水梁 $\mathrm{h}$ を近似的に求められる。逆 に言えば、上流での水深 $\mathrm{h}$ を測定すれば流量 $\mathrm{Q}$ 算定するこ
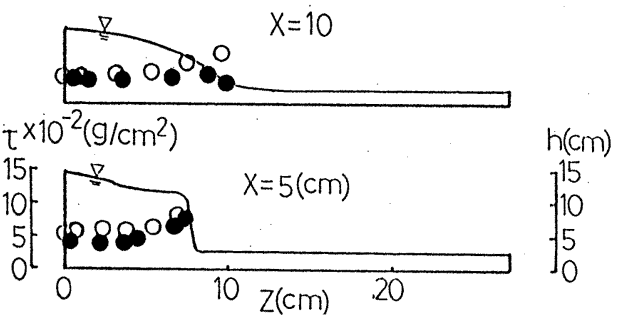
とが可能である。ここで、実際 の狭さく部での水梁が限界水梁 の約 1.3 倍であるととが実験的 にわかっているので（図 13 参照 $h$ 上流水深が知られている場合、 あるいは流量が与えられている 場合には、狭さく部通過時の水 深を算出することができる。こ の水深加ら狭さく部での平均流 速を求め、それぞれの射流遷移 での最大せん断力と比較したも

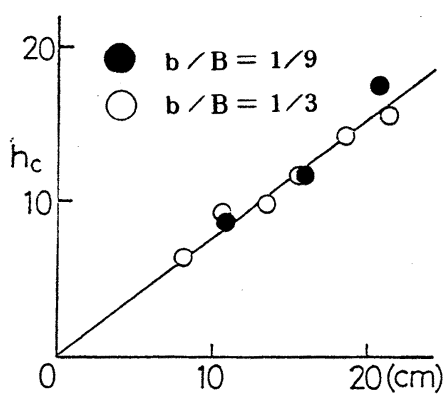

実測の狭さく部水梁

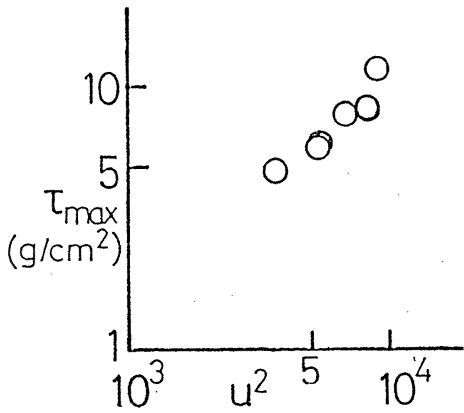

図 14. 狭さく部平均流速之 $\tau_{\max }$ の関係

図 13. 㹟さく部水深と限界水梁の関係 のを図14に示す。最大底面せん断力は狭さく部での平均流速の 2 乗にほぼ比例していると言ってよいだろう。 したがって、狭さくを通過する流れで射流遷移の場合、その最大せん断力をより簡易に知ろうとすればての 方法む利用することができよう。なお最大せん断力は、狭さく通過後の縮流部の外縁で現われる。

\section{7. おわりに}

カルマンの運動量方程式は、その適用法が適切ならば、抵抗則と連立させることにより精度よく底面せん 断力を算定できることがわかった。また、射流遷移に限ればその最大底面せん断力はより簡易な方法で見積 ることも可能である。なお、本研究は文部省科学研究費 (自然災害特別研究(1)都市河川の治水トータルシス テムに関する研究 代表者 吉川秀夫教授) の補助を受けた。また、実験及びその解析に本大学大学院生木 下献一君に協力して頂いたととを記し、ここに謝意を表します。

\section{参考义献}

1)片山道夫・福井吉孝・吉川秀夫 : 段落ち部近傍の底面せん断力、土木学会論文報告集（投稿中） 2) Preston, H : The determination of turbulent skinfriction by means of pitot tubes. 3)石原藤次郎・志方俊之: 開水路急拡部の水理学的性状に関する研究、土木学会論文集、第 128 号 4)東野寛: 急縮部の水理、38 回年次講演会 